\title{
Impact of Corporate Board Meetings on Financial Performance: Evidence from Selected Listed Companies in Nigeria
}

\author{
Joseph, U. B. Azubike ${ }^{1}$, Madugba, Joseph Ugochukwu ${ }^{1} \&$ Okpe, Ikechichukwu Innocent ${ }^{2}$ \\ ${ }^{1}$ Department of Accounting, Michael Okpara University of Agriculture, Umudike Umuahia Abia State, Nigeria \\ ${ }^{2}$ Department of Accounting, Enugu State University of Science and Technology, Enugu, Nigeria \\ Correspondence: Madugba, Joseph Ugochukwu, Department of Accounting, Michael Okpara University of \\ Agriculture, Umudike Umuahia Abia State, Nigeria. E-mail: joeugochukwu@ yahoo.com
}

Received: August 11, 2015

doi:10.5539/ijef.v7n12p268
Accepted: September 19, 2015

Online Published: November 25, 2015

URL: http://dx.doi.org/10.5539/ijef.v7n12p268

\begin{abstract}
The study, impact of Corporate Board Meetings on Financial Performance of selected listed companies in Nigeria tested the impact of Earning per share, Return on capital employed on corporate board meeting of selected listed companies in Nigeria. Simple regression was used to analyze the data gotten from the published financial statement of the companies. The result showed that a unit change in CMB will lead to unit change in EPS. The $(\mathrm{R})^{2}$ showed the probability value of the $\mathrm{t}$-statistic proved to be $<.05$. The study found out that corporate board meeting significantly impacts on Earning per share and this led to the rejection of null hypothesis of hypothesis one. Hypothesis two has a negative result which led to acceptance of the null hypothesis, but it is expected that at the long run, it will improve.
\end{abstract}

Keywords: corporate governance, board meeting, listed companies

\section{Introduction}

As the world is gradually becoming a global market, attentions of corporations have shifted from just profit maximization to success sustenance as this, not only promote shareholders wealth but also the wealth of other stakeholders. For efficient and effective attainment of this objective, the government on its own has through legislations to some extent, allowed the complete freedom of economic activities and the attendant effect has been the wind-up of some corporations such as Enron in 2001 in U.S, WorldCom, Global Grossing and Rank Xerox as well as progress Bank in Nigeria. Co-operative and Commerce Bank, Merchantile Bank among others.

In recent time, there exists different definitions of corporate Governance as opined by Kajola (2009) Corporate Governance is making sure the business is well managed and shareholders interest protected at all times. This implies that the focus of corporate Governance is the maximization of shareholders wealth and its protection. It is equally defined as the system by which business corporations are directed and controlled. Organization for Economic Corporation and Development (OECD) (1999) stated that it involves distribution of rights and responsibilities among different participants in the corporation such as the board managers, shareholders and other stakeholders. It is concerned with the rules and procedures for decision making on corporate objectives and the means of its attainment and the monitoring of performance (Akinsulire, 2006).

Good corporate governance should provide proper incentives for the board and management to pursue objectives that are in the interest of the company and its shareholders and should facilitate effective monitoring. The presence of an effective corporate Governance system, within an individual company and across an economy as a whole, helps to provide a degree of confidence that is necessary for the proper functioning of a market economy (Uwuigbe, 2013). The low rate of economic growth experience in Nigeria is a function of inadequate existing level of corporate Governance since mobilization of capital is affected. Hence, corporate Governance practice in Nigeria is focused on mechanism to improve the confidence and trust of investor in the management and promote economic development of the country. Nworji, Olojunju, Adeyanju (2011) state that the efficacy of corporate Governance structure and practice on corporations operating on highly volatile environment of Nigeria is yet to be investigated.

\subsection{Statement of the Problem}

The collapse of corporations has become an issue of concern to both the investing public and the Government 
over the decades. The manner at which big corporate organizations are financially distressed is also very alarming and challenging. The Government on her own has also made legislations to ensure smooth running and security of the investments of the investors of these corporations. The shareholders and other stakeholders of these corporations are however afraid of losing their investments. The shareholders also feel that their investments are supposed to be secured since they have appointed and entrusted these investments into the hands of their representatives (Directors) who are at the helm of affairs of these corporations. Hence, the need to find out the impact of earning per share on corporate governance of quoted companies in Nigeria.

\subsection{Objectives of the Study}

The major objective of this study is to find out the impact of corporate board meeting on financial performance of selected quoted companies in Nigeria and the following are the specific objectives:

i. To ascertain the impact of earning per share on corporate board meeting of quoted companies in Nigeria.

ii. To ascertain the impact of return on capital employed on corporate board meeting of quoted companies in Nigeria.

\subsection{Research Questions}

The study is fashioned to answer the following questions:

i. What is the impact of earning per share on corporate board meeting of listed companies in Nigeria?

ii. What is the impact of return on capital employed on corporate board meeting of listed companies in Nigeria?

\subsection{Research Hypothesis}

$\mathrm{Ho}_{1}$. Earning per share has no significant impact on corporate board meeting of quoted companies in Nigeria.

$\mathrm{Ho}_{2}$. Return on capital employed has no significant impact on corporate board meeting of quoted companies in Nigeria.

\subsection{Review of Related Literature}

One important theory of corporate Governance is the Agency theory. (Alchian \& Demsetz, 1972). But the effectiveness of the corporate Board is highly based on the frequency of their meetings (Lipton \& Lorsch, 1992). It is believed that the frequency of Board meetings affect corporate performance (Jensen, 1993; Vefeas, 1999). The board plays a crucial role in the governance, conformance and performance of corporations. As firms or corporations grow, in its challenges and opportunities over time, Board authorities and performance of the board are dynamically determined by firm-level heterogeneities such as company culture and managerial talent (Guest, 2009; Ntim, Opong, \& Danbolt 2011b).

Barr, Gerson, and Kanto, B. (1995) opined that corporate context is distinctively characterized by concentrated ownership, greater institutional ownership, but weaker shareholders activities and poor enforcement of corporate laws. Concentrated ownership can limit the effectiveness of market for corporate control (Ntim, 2009; Ntim et al., 2011b) as this may negatively affect the willingness of firms to voluntarily disclose corporate Governance rules, and thereby impairing the capacity of a voluntary code to improve corporate Governance standards by enhancing the independence and monitoring power of the corporate boards.

Corporate boards of directors carry out critical roles, and thus deemed to be an important corporate Governance mechanism (Lipton \& Lonsch, 1992; Jensen, 1993). In a nullshell, corporate boards advise (professional advices, supervise (monitoring) and seek accountability (disciplined) from management to ensure that managers only pursue the interest of shareholders (Jensen \& Meckling, 1976; Ntim, 2009) .

\section{Theoritical Framework}

\subsection{The Agency Theory}

The Agency theory as its name implies has to do with the relationship between the principals such as shareholders and agents such as the company executives and managers. According to the theory, the principals (owners of the company-shareholders) engage the services of the agents (Directors or managers) to mastermind the day-to-day running and administration of the business or corporations (Clarke, 2004). It is important to state that two factors can influence the prominence of agency theory (Dandy, Dalton, \& Canella, 2000). The first is the conceptual and simple theory that reduces the corporation to two participants of managers and shareholders. The second suggest that manager or shareholders in organizations can be self-interested (Alalade, Onadeko, \& Okezie, 2014). This theory posited that shareholders expect the agent to act and make decisions in the principal's 
interest. On the contrary, the agent may not necessarily make decision in the best interest of the principals (Padilla, 2000).

According to Jesen and Meckling (1976), Adam Smith (1887) was the first to identify the agency problem as supported by Ross (1973). The first elaborate explanation of the agency theory was presented by Jesen and Meckling in 1976. The probability of problems emanating from separation of ownership and control in agency theory has been proven by Davis, Schoolmaen, and Donaldson (1997). Suffice it to say that the agent may fall short of confidence between the aspirations of the principals and the agent's pursuit. According to Bhumani (2008) agency theory was mainly introduced as a means for separation of ownership and control Agency theory has its root in economic theory as explored by Alchian and Dumsetz (1972). In a nutshell, according to Lubakin (2005) agency theory states that the role of corporate governance is to facilitate compliance by reducing executive's self-smiling inclinations to compensate risk through opportunistic means.

In a similar study of this nature in South Africa, Ntim and Osei (2011) stated that a statistically significant and positive association exists between the frequency of corporation board meetings and corporate performance, implying that South African board that meet more frequently tend to generate higher financial performance. The study provided an empirical support for agency theory, which suggests that corporate board that meet more frequently have increased capacity to effectively advice, monitor and discipline management, and thereby improving corporate financial performance.

\section{Methodology}

The study utilized ex-post research design. The secondary data used for analysis spanned a seven year period (2008-2014) and comprised Earning per Share (EPS), Return on capital employed (ROCE), corporate board meeting computed from the financial statement of selected quoted companies. The data was analyzed with SPSS 20.0 using simple regression inferential statistics to determine the impact of Earning per share and Return on capital employed as measures of financial performance on corporate board meeting. Earnings per share and Return on capital employed serve as a proxy for financial performance.

\subsection{Model Specification}

To achieve the objective of this study, the following model specifications were formulated thus.

$$
\begin{aligned}
& \mathrm{EPS}=\mathrm{F}(\mathrm{CMB}) \\
& \mathrm{ROCE}=\mathrm{F}(\mathrm{CMB}) \\
& \mathrm{EPS}=\beta_{\mathrm{O}}+\beta_{1 \mathrm{CMB}}+\mu_{1} \\
& \mathrm{ROCE}=\beta_{2}+\beta_{3 \mathrm{CMB}}+\mu_{2}
\end{aligned}
$$

Where EPS $=$ Earnings per share

$\mathrm{CMB}=$ Corporate board meetings

ROCE $=$ Return on capital employed

$\beta_{0} \beta_{2}=$ constant

$\beta_{1} \beta_{3}=$ co-efficient

$\mu_{1} \mu_{2}=$ error/stochastic term

\section{Discussion of Findings}

$\mathbf{H o}_{1}$ : Earning per share has no significant impact on corporate board meeting.

Table 1. Regression result for hypothesis one

\begin{tabular}{lcccc}
\hline \multicolumn{5}{c}{ Model Summary } \\
\hline Model & $\mathrm{R}$ & $\mathrm{R}$ Square & Adjusted R Square & Std. Error of the Estimate \\
\hline 1 & $.527^{\mathrm{a}}$ & .277 & .217 & 210.43682 \\
\hline
\end{tabular}

\footnotetext{
a. Predictors: (Constant), CBM.
} 


\begin{tabular}{|c|c|c|c|c|c|c|}
\hline \multicolumn{7}{|c|}{ Coefficients } \\
\hline \multirow[t]{2}{*}{ Model } & & \multicolumn{2}{|c|}{ Unstandardized Coefficients } & \multirow{2}{*}{$\begin{array}{c}\text { Standardized Coefficients } \\
\text { Beta } \\
\end{array}$} & \multirow[t]{2}{*}{$\mathrm{t}$} & \multirow[t]{2}{*}{ Sig. } \\
\hline & & $\mathrm{B}$ & Std. Error & & & \\
\hline \multirow[t]{2}{*}{1} & (Constant) & -1163.713 & 658.364 & & -1.768 & .103 \\
\hline & $\mathrm{CBM}$ & 294.158 & 137.066 & .527 & 2.146 & .053 \\
\hline
\end{tabular}

a. Dependent Variable: EPS.

Source: Researchers' Estimation, 2015 (see SPSS appendix 2).

The table above shows the regression results of impact of corporate board meeting on Earning per share of selected quoted companies in Nigeria. The result shows that the estimated co-efficient of the regression $(\beta)$ parameters have positive sign and this confirm our apriority expectation. It reveals that impact of corporate board meeting and Earning per share is positive at 294.158 implying that for every unit increase in corporate board meeting, Earning per share is predicted to increase by 294.16 units. The coefficient of correlation (R) gave a value of .527 indicating that the strength of the relation between corporate board meeting and Earning per share is $52.7 \%$. Furthermore, the coefficient of determination $(\mathrm{R})^{2}$ of 0.277 which indicates that corporate board meeting can only explain about $27.7 \%$ of the variation in Earnings per share. Finally, the computed t-statistic for the coefficient of corporate board meeting is 2.146 which is greater than the critical t-statistic of 1.771 at 0.05 level of significance and 13DF. This means that the null hypothesis is rejected. Hence, we conclude that corporate Board meeting has a significant impact on the Earning per share of selected quoted companies in Nigeria.

$\mathbf{H o}_{2}$ : Return on capital Employed has no significance impact on corporate Board meeting.

Table 2. Regression result for hypothesis two

\begin{tabular}{lcccc}
\hline \multicolumn{5}{c}{ Model Summary } \\
\hline Model & $\mathrm{R}$ & $\mathrm{R}$ Square & Adjusted R Square & Std. Error of the Estimate \\
\hline 1 & $.160^{\mathrm{a}}$ & .025 & -.056 & 26.30702 \\
\hline
\end{tabular}

a. Predictors: (Constant), CBM.

\begin{tabular}{llrrrrrr}
\hline \multirow{2}{*}{ Model } & & \multicolumn{2}{c}{ Unstandardized Coefficients } & \multicolumn{2}{c}{ Standardized Coefficients } & \multirow{2}{*}{ S } & \multirow{2}{*}{ Sig. } \\
\cline { 3 - 7 } & & B & Std. Error & Beta & & .364 \\
\hline 1 & (Constant) & 77.596 & 82.303 & & -.160 & -.560 & .586 \\
\hline
\end{tabular}

a. Dependent Variable: ROCE.

Source: Researchers' Estimation, 2015 (see SPSS appendix 3).

The table above shows the regression results of the impact of Return on capital Employed on corporate board meeting. The regression result is negative. Implying that the frequency unit increase in corporation board meeting, Return on capital employed is predicted to decrease by 9.601 units.

The coefficient of correlation $(\mathrm{R})$ gave a value of 1.60 implying that the strength of impact between corporate board meeting and Return on capital Employed is very weak at 16\%. Furthermore, the coefficient of determination $(\mathrm{R})^{2}$ of 0.025 indicates that corporate board meeting can only explain about $2.5 \%$ of the variations in Return on capital employed. Finally, the computed t-statistic for the coefficient of corporate board meeting is 0.586 which is less than the critical t-statistic of 1.771 at 0.05 level of significance and 13DF. This means that the null hypothesis is accepted. Hence, we conclude that corporate board meetings have no significant impact on the return on capital employed of quoted companies in Nigeria.

\section{Conclusion and Recommendations}

The study concluded that Earning per share has a positive significant impact on corporate board meeting. This implies that corporate boards that meet often generate higher and better financial performance than those that do not meet often. This conclusion is in line with agency theory and Ntim and Osei (2011), who found out in their study that corporate board meeting has a positive and significant impact on corporate performance. Furthermore, from the statistical analysis, corporate board meeting has a negative impact on Return on capital employed. The researchers are of the opinion that on the long run, it will have a positive impact on it and that it is still an important variable for measuring financial performance. Hence, the following recommendations were made. 
1) Government should through legislation ensure that quoted company Boards meet more regularly as it will improve the performance of the company.

2) Quoted companies should be meant to publish only the correct information about their financial position.

3) All quoted companies should be made to publish their statement of financial position on the Internet to enhance access for further research.

\section{References}

Akinsulire, O. (2006). Financial management (4th ed.). Lagos: El-Toda Ventures.

Alchian, A. A., \& Demsetz, H. (1972). Production, information Costs and Economic Organization. American Economic Review, 62, 772-795.

Barr, G., Gerson, J., \& Kanto, B. (1995). Shareholders as Agent and principals: The Case for South Africa's Corporate Governance System. Journal of Applied Corporate Finance, 8. http://dx.doi.org/10.1111/j.1745-6622.1995.tb00268.x

Clark, T. (2004). Theories of Corporate Governance: The Philosophical Foundations of Corporate Governance. New York: Routledge Publishing.

Davis, J. H., Schooman, F. D., \& Donaldson, L. (1997). Toward a stewardship theory of Management. Academy of Management Review, 22, 20-47.

Guest, P. M. (2009). The Impact of Board Size on Firm Performance: Evidence from the UK. European Journal of Finance, 15, 385-404. http://dx.doi.org/10.1080/13518470802466121

Jensen, M. C. (1993). The Modern Industrial Revolution, Exit, and the Failure of Internal Control System. Journal of Finance, 48, 831-880. http://dx.doi.org/10.1111/j.1540-6261.1993.tb04022.x

Jensen, M. C., \& Meekling, W. H. (1976). Theory of the Firm: Managerial Behaviour, Agency Costs and Ownership Structure. Journal of Financial Economics, 305-360. http://dx.doi.org/10.1016/0304-405X(76)90026-X

Lipton, M., \& Lorsch, J. (1992). A Modest Proposal for Improved Corporate Governance. Business Lawyer, 48, 59-77.

Lubatkin, M., Lane, P., Collins, S. O. M., \& Very, P. (2005). Origin of corporate governance in the USA. Sweden and France Organization Studies, 26(6), 867-888. http://dx.doi.org/10.1177/0170840605054602

Ntim, C. G. (2009). Internal corporate governance and firm financial performance: Evidence from South African listed firms. $\mathrm{PhD}$ thesis, University of Glasgow

Ntim, C. G., \& Osei, K. A. (2011). The impact of corporate Board meetings on Corporate performance in South Africa. African Review of Economics and Finance, 2(2), 2011.

Ntim, C. G., Opong K. K., \& Danbolt, J. (2011). The value Relevance of Shareholder versus Stakeholder Corporate Governance Disclosure Policy Reform in South Africa. Corporate Governance: An International Review, Forthcoming.

Ntim, C. G., Opong, K. K., Danbolt, J., \& Thomas, D. A. (2011).Voluntary Corporate Governance Disclosures by Post-Apartheid South African Corporations. Journal of Applied Accounting Research, Forthcoming.

Nworji, I. D., Olagunju, A., \& Adeyanju, D. O. (2011). Corporate Governance and Bank Failure in Nigeria: Issues, Challenges and Opportunities. Research Journal of Finance and Accounting, 2(2).

Okoye, V. (2013). Analysis of Corporate Governance and the performance of pension Scheme in Nigeria. International journal of Business and Administration, 2(1), 15-20.

Organization for Economic Co-Operation and Development. (2004). OECD Principles of Corporate Governance. Paris Cedex 16, France: OECD Publications Service.

Padilia, A. (2002). Can Agency Theory Justify the Regulation of Insider Trading? The Quarterly Journal of Austrian Economics, 5(1), 3-38. http://dx.doi.org/10.1007/s12113-002-1015-6

Vefeas, N. (1999a). Board Meeting Frequency and Firm Performance. Journal of Financial Economics, 53, 113-142. http://dx.doi.org/10.1016/S0304-405X(99)00018-5

Vefeas, N. (1999b). The Nature of Board Nominating Committees and their Role in Corporate Governance. Journal of Business Finance \& Accounting, 26(1\&2), 199-225. http://dx.doi.org/10.1111/1468-5957.00253 
Yimka, S. A. A., Babatunde, B. O., \& Okezie, F. O. (2014). Corporate Governance Practices and Firms' Financial Performance of Selected Manufacturing Companies in Lagos State, Nigeria. International Journal of economics, Finance and Management Sciences, 2(5), 285-296. http://dx.doi.org/10.11648/j.ijefm.20140205.13

Appendix 1

\begin{tabular}{|c|c|c|c|c|c|c|c|c|c|c|c|c|c|c|}
\hline \multirow[b]{2}{*}{ Year } & \multicolumn{7}{|c|}{ HONEY WELL } & \multicolumn{7}{|c|}{ NIG BREWERIES } \\
\hline & 2008 & 2009 & 2010 & 2011 & 2012 & 2013 & 2014 & 2008 & 2009 & 2010 & 2011 & 2012 & 2013 & 2014 \\
\hline EPS & 4.87 & 14.81 & 19.08 & 20.08 & 26.67 & 35.85 & 42.26 & 340.00 & 369.00 & 401.00 & 508.00 & 503.00 & 570.00 & 562.00 \\
\hline CMB & 4.00 & 4.00 & 4.00 & 5.00 & 5.00 & 5.00 & 5.00 & 5.00 & 5.00 & 5.00 & 5.00 & 5.00 & 5.00 & 5.00 \\
\hline CBS & 9.00 & 9.00 & 9.00 & 9.00 & 9.00 & 9.00 & 9.00 & 14.00 & 13.00 & 15.00 & 15.00 & 15.00 & 15.00 & 15.00 \\
\hline ROCE & 49.74 & 29.65 & 38.19 & 41.66 & 53.38 & 71.80 & 84.63 & 6.80 & 7.38 & 11.89 & 15.14 & 10.06 & 11.39 & 11.39 \\
\hline
\end{tabular}

Appendix 2

\begin{tabular}{llcc}
\hline & \multicolumn{2}{c}{ Correlations } & \\
\hline \multirow{3}{*}{ Pearson Correlation } & & EPS & CBM \\
\cline { 2 - 4 } & EPS & 1 & 0.527 \\
Sig. (1-tailed) & CBM & 0.527 & 1 \\
& EPS & $\cdot$ & 0.027 \\
$\mathrm{~N}$ & CBM & 0.027 & $\cdot$ \\
& EPS & 14 & 14 \\
\hline
\end{tabular}

\begin{tabular}{lcccc}
\hline \multicolumn{5}{c}{ Model Summary } \\
\hline Model & $\mathrm{R}$ & $\mathrm{R}$ Square & Adjusted R Square & Std. Error of the Estimate \\
\hline 1 & $.527^{\mathrm{a}}$ & 0.277 & 0.217 & 210.43682 \\
\hline
\end{tabular}

a. Predictors: (Constant), CBM.

\begin{tabular}{llccccc}
\hline \multicolumn{7}{c}{ ANOVA $^{\mathbf{b}}$} \\
\hline Model & & Sum of Squares & Df & Mean Square & F & Sig. \\
\hline \multirow{3}{*}{1} & Regression & 203961.299 & 1 & 203961.299 & 4.606 & $.053^{\mathbf{a}}$ \\
& Residual & 531403.838 & 12 & 44283.653 & & \\
& Total & 735365.137 & 13 & & & \\
\hline
\end{tabular}

a. Predictors: (Constant), CBM.

b. Dependent Variable: EPS.

\begin{tabular}{llccccc}
\hline \multirow{2}{*}{ Model } & & \multicolumn{2}{c}{ Unstandardized Coefficients } & Standardized Coefficients & \multirow{2}{*}{ t } & \\
\cline { 3 - 6 } & & $\mathrm{B}$ & Std. Error & Beta & & \\
\cline { 3 - 6 } 1 & (Constant) & -1163.713 & 658.364 & & 0.103 \\
& CBM & 294.158 & 137.066 & 0.527 & 2.146 & 0.053 \\
\hline
\end{tabular}

a. Dependent Variable: EPS.

\section{Appendix 3}

\begin{tabular}{lccc}
\hline \multicolumn{4}{c}{ Correlations } \\
\hline \\
\hline \multirow{2}{*}{ Pearson Correlation } & & ROCE & CBM \\
\multirow{2}{*}{ Sig. (1-tailed) } & ROCE & 1 & -0.16 \\
& CBM & -0.16 & 1 \\
$\mathrm{~N}$ & ROCE & $\cdot$ & 0.293 \\
& CBM & 0.293 & $\cdot$ \\
& ROCE & 14 & 14 \\
\hline
\end{tabular}




\begin{tabular}{lcccc}
\hline \multicolumn{5}{c}{ Model Summary } \\
\hline Model & $\mathrm{R}$ & $\mathrm{R}$ Square & Adjusted R Square & Std. Error of the Estimate \\
\hline 1 & $.160^{\mathrm{a}}$ & 0.025 & -0.056 & 26.30702 \\
\hline
\end{tabular}

a. Predictors: (Constant), CBM.

\begin{tabular}{llccccc}
\hline \multicolumn{7}{c}{ ANOVA $^{\mathbf{b}}$} \\
\hline Model & & Sum of Squares & Df & Mean Square & F & Sig. \\
\hline \multirow{3}{*}{1} & Regression & 217.262 & 1 & 217.262 & 0.314 & $.586^{\text {a }}$ \\
& Residual & 8304.71 & 12 & 692.059 & & \\
& Total & 8521.972 & 13 & & & \\
\hline
\end{tabular}

a. Predictors: (Constant), CBM.

b. Dependent Variable: ROCE.

\begin{tabular}{|c|c|c|c|c|c|c|}
\hline \multirow{2}{*}{ Model } & & \multicolumn{2}{|c|}{ Unstandardized Coefficients } & \multirow{2}{*}{$\begin{array}{c}\text { Standardized Coefficients } \\
\text { Beta } \\
\end{array}$} & \multirow{2}{*}{$\mathrm{t}$} & \multirow{2}{*}{ Sig. } \\
\hline & & $\mathrm{B}$ & Std. Error & & & \\
\hline \multirow{2}{*}{1} & (Constant) & 77.596 & 82.303 & & 0.943 & 0.364 \\
\hline & CBM & -9.601 & 17.135 & -0.16 & -0.56 & 0.586 \\
\hline
\end{tabular}

a. Dependent Variable: ROCE.

\section{Copyrights}

Copyright for this article is retained by the author(s), with first publication rights granted to the journal.

This is an open-access article distributed under the terms and conditions of the Creative Commons Attribution license (http://creativecommons.org/licenses/by/3.0/). 